\title{
Hypoglycemic effect of the hydroalcoholic extract of leaves of Averrhoa carambola L. (Oxalidaceae)
}

\author{
Edilene B. Ferreira, ${ }^{1}$ Luiz Claudio Fernandes, ${ }^{2}$ Sharize B. Galende, ${ }^{3}$ Diogenes A. G. \\ Cortez, ${ }^{1}$ Roberto B. Bazotte ${ }^{*, 1}$
}

${ }^{1}$ Departamento de Farmácia e Farmacologia, Universidade Estadual de Maringá, Avenida Colombro, 5790, 87020-900 Maringá-PR, Brazil,

${ }^{2}$ Departamento de Fisiologia, Universidade Federal do Paraná, Caixa Postal 19031, 81530-990 Curitiba-PR, Brazil,

${ }^{3}$ Programa de Pós Graduação em Ciências Farmacêuticas, Universidade Estadual de Maringá, Avenida Colombro, 5790, 87020-900 Maringá-PR, Brazil

\begin{abstract}
RESUMO: "Efeito hipoglicemiante do extrato hidroalcoólico de folhas de Averrhoa carambola L. (Oxalidaceae)". O efeito do tratamento via oral $(20 \mathrm{mg} / \mathrm{kg}$ x day) com extrato hidroalcoólico de folhas de Averrhoa carambola L. (EHFC) sobre a glicemia de jejum (15 h) foi examinada ao compararmos ratos que receberam veículo (Grupo controle) ou EHFC (Grupo EHFC) durante 15 dias. O grupo EHFC apresentou menor glicemia de jejum $(\mathrm{p}<0,05)$. Em contraste, o grupo EHFC apresentou maior $(\mathrm{p}<0,05)$ produção hepática glicose a partir de L-alanina $(5 \mathrm{mM})$. Este efeito foi mediado, pelo menos parcialmente, pela ativação do catabolismo da L-alanina, inferido pela maior produção hepática de uréia $(\mathrm{p}<0,05)$ e L-lactato $(\mathrm{p}<0,05)$. Diferente da L-alanina, a produção hepática de glicose a partir de L-glutamina $(5 \mathrm{mM})$, L-lactato $(2 \mathrm{mM})$ e glicerol $(2$ $\mathrm{mM}$ ) no grupo EHFC foi similar ao grupo controle. Adicionalmente, o efeito do tratamento com EHFC sobre a captação de glicose no músculo soleus, inferida pela incorporação de $\left[{ }^{14} \mathrm{C}\right]$-glicose em glicogênio (síntese de glicogênio) e produção de $\left[{ }^{14} \mathrm{C}\right]$-lactato foi investigada, verificando-se resultados semelhantes nos dois grupos. Assim, concluiu-se que a redução da glicemia de jejum promovida pelo tratamento com EHFC não foi mediada por inibição da gliconeogenese hepática e/ou aumento da captação muscular de glicose.
\end{abstract}

Unitermos: Averrhoa carambola, Oxalidaceae, carambola, gliconeogenese, plantas antidiabeticas, efeito hipoglicemiante.

\begin{abstract}
The effect of the oral treatment (20 mg/kg x day) with the hydroalcoholic extract of leaves of Averrhoa carambola L. (HELAC) on fasting glycemia (15 h) was examined. For this purpose, rats that received vehicle (Control group) or HELAC (HELAC group) during 15 days were compared. HELAC group showed lower fasting glycemia $(\mathrm{p}<0.05)$. In contrast, livers from HELAC group showed higher $(\mathrm{p}<0.05)$ glucose production from L-alanine $(5 \mathrm{mM})$. This effect was mediated, at least part of it, by an activation of the catabolism of L-alanine inferred by the increased hepatic urea $(\mathrm{p}<0.05)$ and L-lactate $(\mathrm{p}<0.05)$ production. Differently of L-alanine, the glucose production from L-glutamine $(5 \mathrm{mM})$, L-lactate $(2 \mathrm{mM})$ and glycerol $(2 \mathrm{mM})$ was similar (Control group vs. HELAC group). In addition, the HELAC treatment did not change the glucose uptake in soleus muscles, inferred by the incorporation of $\left[{ }^{14} \mathrm{C}\right]$-glucose to glycogen (glycogen synthesis) and $\left[{ }^{14} \mathrm{C}\right]$-lactate production. Thus, we can conclude that the reduction of fasting glycemia promoted by the treatment with HELAC was not mediated by an inhibition of hepatic gluconeogenesis and/or an increased glucose uptake by muscles.
\end{abstract}

Keywords: Averrhoa carambola, Oxalidaceae, star fruit, gluconeogenesis, antidiabetic plants, hypoglycemic effect.

\section{INTRODUCTION}

Averrhoa carambola L. (Oxalidaceae) is known as star fruit and other names specific to different countries. In Brazil this popular tropical fruit is commonly called "Carambola", and it is usually consumed as fresh fruit or as juice fruit.
Several studies have reported that patients with chronic renal failure develop severe neurological disturbs after eating carambola fruit or drinking its juice (Neto et al., 1998). This intoxication, caused by a neurotoxin (Carolino et al., 2005) is treated with hemodialysis (Wang et al., 2006). However, in many cases death is not preventable (Chang et al., 2000). In 
addition, an oxalate nephropathy with permanent renal injury after chronic ingestion of carambola was recently demonstrated (Niticharoenpong et al., 2006). Moreover, the fruit of carambola also promotes an inhibition human cytochrome P450 3A activity (Hidaka et al., 2004).

On the other hand, studies suggesting toxicity to carambola leaves are absent. In agreement, our previous investigation (Provasi et al., 2001) did not find acute toxicity of carambola leaves in mouse, rats and dogs. In addition, considering that in Brazil carambola leaves is recommended to treat diabetes (Martha et al., 2000) our purpose was investigate the antidiabetic potential of carambola leaves.

Because a hypoglycemic effect was previously demonstrated by using hydroalcoholic extract of leaves of Averrhoa bilimbi (Pushparaj et al., 2000). In the present study the effect of oral treatment with hydroalcoholic extract of leaves of Averrhoa carambola (HELAC) on fasting glycemia was examined. Moreover, the effects of HELAC on hepatic glucose production and muscle glucose uptake were investigated.

\section{MATERIAL AND METHODS}

\section{Plant materials and preparation of the extracts}

Averrhoa carambola L. (Oxalidaceae) was collected in Maringá, State of Paraná, Brazil (September, 2000), prepared and stored for reference at the Herbarium of Universidade Estadual de Maringá (code 8101).

HELAC obtained by a method previously described (Provasi et al., 2005), was lyophilized and dissolved in water immediately before using.

\section{Animals and treatment}

Male Wistar rats weighing about $200 \mathrm{~g}$, were individually caged and maintained on standard rodent chow and water ad libitum. The manipulation of the animals followed the Brazilian law on the protection of animals.

The rats received HELAC (HELAC group) or vehicle (Control group) at 5:00 pm. during 15 days. The amount $(20 \mathrm{mg} / \mathrm{kg}$ x day), administration (orally by gavage) and period of treatment were similar to that previously employed (Ferreira et al., 2006) to obtain hypoglycemic effects with Stevia rebaudiana leaves.

\section{Determination of glycemia}

After 15 days of treatment, HELAC and vehicle groups were subdivided in four subgroups: HELACFed, HELAC-Fasted, Control- Fed and Control-Fasted subgroups. Fed subgroups were maintained with free access to food until the blood collection. Fasted subgroups were maintained without food ( $15 \mathrm{~h}$ ) until the blood collection. All rats were killed by decapitation.

Blood was immediately collected, centrifuged and the glycemia was determined (Bergmeyer and Bernt, 1974).

\section{Liver perfusion experiments}

After 15 days of treatment, the rats were anaesthetized by an intraperitoneal injection of sodium thiopental $(45 \mathrm{mg} / \mathrm{Kg})$ and submitted to laparotomy. The livers were perfused according to the protocol previously described (Ferreira et al., 2006).

All liver perfusion experiments were performed with $15 \mathrm{~h}$ fasted rats, a favourable condition for gluconeogenesis, at which hepatic glycogen was completely depleted (Batista et al., 1997).

After a pre-infusion period, the gluconeogenic precursor (L-alanine, L-lactate, L-glutamine or glycerol) was dissolved in the perfusion fluid and infused during $20 \mathrm{~min}$, followed by a period of post-infusion to allow the return to basal glucose production. Samples of the effluent perfusion fluid were collected at $2 \mathrm{~min}$ intervals and the glucose production was determined (Bergmeyer and Bernt, 1974). The differences in the glucose production during and before the infusion of the gluconeogenic substrate allowed calculating the areas under the curves (AUC), expressed as $\mu \mathrm{mol} / \mathrm{g}$.

To obtain the maximal capacity of the liver to produce glucose, liver perfusion experiments using increasing concentrations of L-alanine, L-lactate, L-glutamine and glycerol were performed. The addition of these glucose precursors increased the rate of glucose production in a dose-dependent way proportionately to the amount of precursor until the liver capacity was reached, i.e., the lowest concentration at which the maximal hepatic glucose production was obtained. The values obtained to L-alanine, L-lactate, L-glutamine or glycerol were respectively $5 \mathrm{mM}, 2 \mathrm{mM}, 5 \mathrm{mM}$ and 2 $\mathrm{mM}$ (not shown).

Moreover, in part of the liver perfusion experiments L-lactate (Gutmann and Wahlefeld, 1974), pyruvate (Czok and Lamprecht, 1974) and urea (Gutmann and Bergmeyer, 1974) production were measured. Thus, the AUCs shown in the Tables 2-4 were obtained from these liver perfusion experiments.

\section{Soleus muscle experiments}

To measure glucose uptake the incorporation of $\left[{ }^{14} \mathrm{C}\right]$-glucose to glycogen and the $\left[{ }^{14} \mathrm{C}\right]$-lactate production in soleus muscles were done. For this purpose soleus muscles were isolated and incubated as previously described (Massao-Hirabara et al., 2003). Rats were killed by cervical dislocation and soleus muscles were rapidly and carefully isolated, split longitudinally in two equal portions, weighed (20-30 $\mathrm{mg}$ ) and pre-incubated for $30 \mathrm{~min}$, at $37^{\circ} \mathrm{C}$, in KrebsRinger bicarbonate buffer pre-gassed for 30 min with 
$\mathrm{O}_{2} / \mathrm{CO}_{2}$ mixture $(95 / 5 \%)$, containing $5.6 \mathrm{mM}$ glucose, BSA $1 \%, \mathrm{pH} 7.4$, with shaking. After this period, the muscles were transferred to other vials containing the same buffer, but added with $0.3 \mu \mathrm{Ci} / \mathrm{ml} \mathrm{D}-\left[\mathrm{U}-{ }^{14} \mathrm{C}\right]-$ glucose (Amersham $306 \mathrm{mCi} / \mathrm{mmol}$ ). Incubation was then performed for $1 \mathrm{~h}$ under similar conditions, in the presence of vehicle (control), insulin $(1 \mathrm{mU} / \mathrm{ml})$ or HELAC. After the incubation period, glycogen synthesis (measured as ${ }^{14} \mathrm{C}$ incorporation from $\left[\mathrm{U}_{-}{ }^{14} \mathrm{C}\right]$-glucose) and $\left[{ }^{14} \mathrm{C}\right]$-lactate production were measured by liquid scintillation spectroscopy.

\section{Statistical analysis}

Results are reported as means \pm S.D. The program GraphPad Prism was used to calculate the AUC. Data were analyzed statistically by the unpaired Student's t-test or one way ANOVA followed by Tukey test. $p<0.05$ was accepted for all comparisons.

\section{RESULTS AND DISCUSSION}

Since our first study demonstrating antidiabetic properties of Stevia rebaudiana leaves (Curi et al., 1986), we have been investigating the hypotensive (Ferri et al., 2006), antiobesity (Siqueira et al., 2006), hypolipidemic (Silva et al., 2004) and antidiabetic (Galletto et al., 2004) properties of the Brazilian plants.

The data demonstrated that the treatment with HELAC decreased glycemia $(p<0.05)$ in fasted, but not in fed rats (Table 1). Moreover, the lower glycemia observed with chronic treatment with HELAC, was not observed with one isolated dose of HELAC (not shown).

Table 1. Effect of the treatment $(20 \mathrm{mg} / \mathrm{kg} \mathrm{x}$ day $)$ with hydroalcoholic extract of leaves of Averrhoa carambola L. (HELAC group) or vehicle (Control group) on glycemia. HELAC was administered by gavage at 5:00 p.m. during 15 days. Blood samples were collected from fed and $15 \mathrm{~h}$ fasted rats. Data are mean \pm SD of 6-8 animals.

\begin{tabular}{ccc}
\hline & \multicolumn{2}{c}{ Values of Glycemia $(\mathrm{mg} / \mathrm{dl})$} \\
\cline { 2 - 3 } Fed & Control Group & HELAC Group \\
Fasted & $132.10 \pm 9.03$ & $129.8 \pm 6.54$ \\
\hline
\end{tabular}

$* \mathrm{p}<0.05$ as compared with Control group.

Because hepatic gluconeogenesis is crucial for glucose maintenance during fasting (Borba-Murad et al., 2005) this metabolic pathway was investigated in livers from rats treated with HELAC (HELAC group) and compared with Control group.

HELAC group showed higher hepatic glucose production $(\mathrm{p}<0.05)$ from $\mathrm{L}$-alanine (Table 2$)$. This effect was probably the result of the increased catabolism of
L-alanine. In agreement the livers from HELAC group showed higher $(p<0.05)$ production of urea and L-lactate from L-alanine (Table 2).

Table 2. Glucose, urea, pyruvate and L-lactate production from L-alanine $(5 \mathrm{mM})$ in isolated perfused liver from $15 \mathrm{~h}$ fasted rats that received treatment with hydroalcoholic extract of leaves of Averrhoa carambola L. (HELAC group) or vehicle (Control group). HELAC (20 mg/ $\mathrm{kg}$ x day) or water was administered by gavage during 15 days. The values of the area under the curves (AUC) were calculated as described in Methodology. The data are mean \pm SD of 3-6 experiments.

\begin{tabular}{lcc}
\hline \multirow{2}{*}{ Parameters } & \multicolumn{2}{c}{ Values of AUC $(\mu \mathrm{mol} / \mathrm{g})$} \\
\cline { 2 - 3 } Glucose & Control Group & HELAC Group \\
Urea & $5.44 \pm 0.5$ & $7.69 \pm 0.5^{*}$ \\
Pyruvate & $22.5 \pm 1.3$ & $28.44 \pm 2.6^{*}$ \\
L-Lactate & $4.96 \pm 0.4$ & $4.54 \pm 0.1$ \\
\hline
\end{tabular}

$* \mathrm{p}<0.05$ as compared with Control group.

The increased availability of L-lactate in the hepatocyte favored gluconeogenesis (Gazola et al., 2007) and helps to explain the largest hepatic glucose production during the infusion of L-alanine. Moreover, this effect was selective to L-alanine, since hepatic glucose production from L-lactate, L-glutamine and glycerol was unchanged (Table 3).

Table 3. Glucose production from L-lactate $(5 \mathrm{mM})$, Lglutamine $(5 \mathrm{mM})$ or glycerol $(2 \mathrm{mM})$ in isolated perfused livers from $15 \mathrm{~h}$ fasted rats that received treatment with hydroalcoholic extract of leaves of Averrhoa carambola L. (HELAC group) or vehicle (Control group). HELAC (20 $\mathrm{mg} / \mathrm{kg} \times$ day) or water was administered by gavage during 15 days. The values of area under the curves (AUC) were calculated as described in Methodology. Data are mean \pm SD of 3-4 experiments.

\begin{tabular}{lcc}
\hline Parameters & \multicolumn{2}{c}{ Values of AUC $(\mu \mathrm{mol} / \mathrm{g})$} \\
\cline { 2 - 3 } & Control Group & HELAC Group \\
Glucose from L-lactate & $11.7 \pm 0.3$ & $12.0 \pm 0.5$ \\
$\begin{array}{l}\text { Glucose from L- } \\
\text { glutamine }\end{array}$ & $17.7 \pm 1.2$ & $17.7 \pm 1.6$ \\
Glucose from glycerol & $7.2 \pm 0.1$ & $8.7 \pm 1.2$ \\
\hline $\begin{array}{l}\text { p }>0.05 \text { for all comparisons } \\
\text { group). (Control group }\end{array}$ & vs. HELAC \\
\end{tabular}

At this moment its is important to emphasize that the results showed here contrast with the effect of the treatment with Stevia rebaudiana where a decreased fasting glycemia was associated with a decreased hepatic gluconeogenesis (Ferreira et al., 2006)

Thus a question can be raised: how can we explain the lower fasting glycemia (Table 1) in rats treated with HELAC if the hepatic glucose production from the main gluconeogenic substrate, i.e., L-alanine (Gazola et al., 2007) was increased. One explanation 
for this discrepancy could be the fact that the increased glucose production from L-alanine could reflect a compensatory mechanism to protect against hypoglycemia. In agreement with this suggestion a number of investigations have demonstrated an increased gluconeogenesis during hypoglycemia (Davis et al., 1995; Gazola et al., 2007).

Because an increased muscle glucose uptake must be involved in the decreased fasting glycemia showed by HELAC group, this possibility was investigated. The glucose uptake was inferred by the glycogen synthesis and L-lactate production in isolated soleus muscle. The results showed that in contrast with insulin (positive control), HELAC did not promote activation of glycogen synthesis (Figure 1) and L-lactate production (Figure 2).

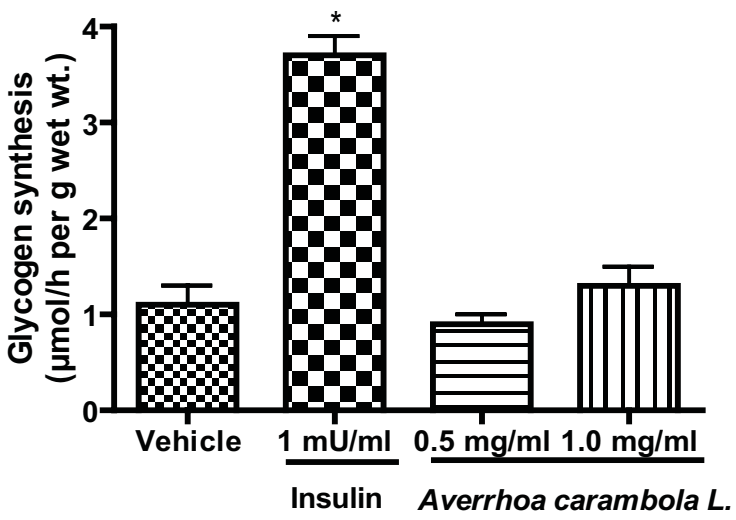

Figure 1. Effects of vehicle (control group), insulin $(1 \mathrm{mU} / \mathrm{ml})$ and hydroalcoholic extract of leaves of Averrhoa carambola $\mathrm{L}(0.5 \mathrm{mg} / \mathrm{ml}$ or $1.0 \mathrm{mg} / \mathrm{ml})$ on glycogen synthesis (measured as ${ }^{14} \mathrm{C}$ incorporation from $\left[\mathrm{U}-{ }^{14} \mathrm{C}\right]$-glucose) in isolated soleus muscle. Values are mean $\pm \mathrm{SD}(\mathrm{n}=4)$. ${ }^{*} \mathrm{p}<0.05$ compared to control group (one way ANOVA followed by Tukey test).

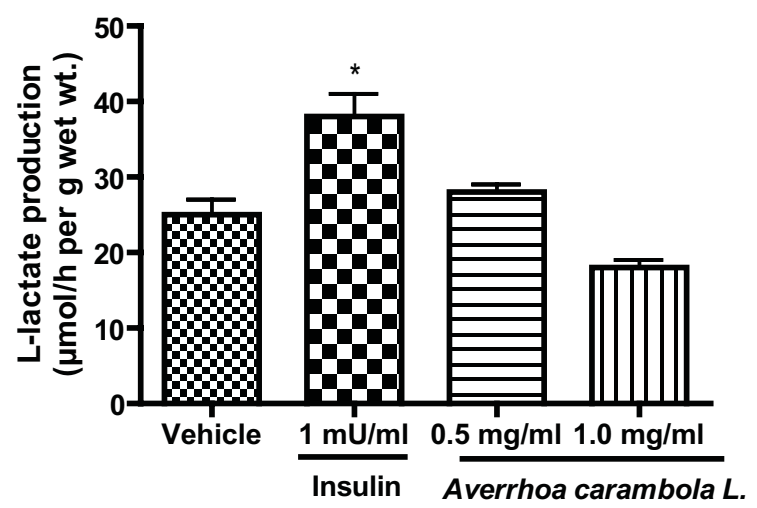

Figure 2. Effects of vehicle (control group), insulin (1 mU/ml) and hydroalcoholic extract of leaves of Averrhoa carambola $\mathrm{L}(0.5 \mathrm{mg} / \mathrm{ml}$ or $1.0 \mathrm{mg} / \mathrm{ml})$ on L-lactate production from glucose $5.6 \mathrm{mM}$ in isolated soleus muscle. Values are mean \pm SD $(\mathrm{n}=4) .{ }^{*} \mathrm{p}<0.05$ compared to control group (one way ANOVA followed by Tukey test).
The results confirmed the popular reputation of carambola to reduce glycemia. However, the reduction of fasting glycemia promoted by the treatment with HELAC was not mediated by an inhibition of hepatic gluconeogenesis and/or an increased glucose uptake by muscles. Therefore, considering that HELAC contain triterpenoids, tanines, biogenic amines, amino acids (Provasi et al., 2001) and a thousand of other compounds, the isolation of the hypoglycemic agent will be necessary in future studies.

\section{ACKNOWLEDGMENTS}

We wish to thank Carlos Eduardo de Oliveira for his technical help and Fundação Araucária, State of Paraná, Brazil (Grant number 5684) for the financial support.

\section{REFERENCES}

Batista MR, Ferraz M, Bazotte RB 1997. Are physiological changes in meal-fed rats determined by the amount of food ingested in the last meal or due to feeding schedule? Physiol Behav 62: 249-253.

Bergmeyer HU, Bernt E 1974. Determination of glucose with glucose oxidase and peroxidase. In: HU Bergmeyer (Ed.), Methods of enzymatic analysis, Verlag ChemieAcademic Press, New York, p. 1205-1215.

Borba-Murad GR, Mario EG, Bassoli BK, Bazotte RB, Souza HM 2005. Comparative acute effects of leptin and insulin on gluconeogenesis and ketogenesis in perfused rat liver. Cell Biochem Funct 23: 405-413.

Carolino RO, Beleboni RO, Pizzo AB, Vecchio FD, GarciaCairasco N, Moyses-Neto M, Santos WF, CoutinhoNetto J 2005. Convulsant activity and neurochemical alterations induced by a fraction obtained from fruit Averrhoa carambola (Oxalidaceae: Geraniales). Neurochem Int 46: 523-531.

Chang JM, Hwang SJ, Kuo HT, Tsai JC, Guh J, Chen HC, Tsai JH, Lai YH 2000. Fatal outcome after ingestion of star fruit (Averrhoa carambola) in uremic patients. Am J Kidney Dis 35: 189-193.

Curi R, Alvarez M, Bazotte RB, Botion LM, Godoy JL, Bracht A 1986. Effect of Stevia rebaudiana on glucose tolerance in normal adult humans. Braz J Med Biol Res 19: 771-774.

Czok R, Lamprecht W 1974. Pyruvate, phosphoenolpyruvate and D-glycerate 2-phosfate. In: Methods of Enzymatic Analysis. Edited by Bermeyer HU. Academic Press, New York, USA; Vol. 2, p. 1446-1448.

Davis SN, Dobbins R, Tarumi C, Jacobs J, Neal D, Cherrington AD 1995. Paradoxical insulin-induced increase in gluconeogenesis in response to prolonged hypoglycemia in conscious dogs. Am J Physiol 2 68: E521-530

Ferreira EB, Neves FAR, Costa MAD, Prado WA, Ferri LAF, Bazotte RB 2006. Comparative effects of Stevia rebaudiana (Bert.) Bertoni leaves and stevioside on glycemia and hepatic gluconeogenesis. Planta Med 72: 691-696. 
Ferri LAF, Alves-Do-Prado W, Yamada SS, Gazola S, Batista MR, Bazotte RB 2006. Investigation of the antihypertensive effect of oral crude stevioside in patients with mild essential hypertension. Phytother Res 20: 732-736.

Galletto R, Siqueira VLD, Ferreira EB, Oliveira AJB, Bazotte RB 2004. Absence of antidiabetic and hypolipidemic effect of Gymnema sylvestre in both non-diabetic and alloxan-diabetic rats. Braz Arch Biol Technol 47: $545-551$

Gazola VA, Garcia RF, Curi R, Pithon-Curi TC, Mohamad MS, Hartmann EM, Barrena HC, Bazotte RB 2007. Acute effects of isolated and combined L-alanine and L-glutamine on hepatic gluconeogenesis, ureagenesis and glycaemic recovery in experimental short-term insulin induced hypoglycaemia. Cell Biochem Funct 25: $211-216$.

Gutmann I, Wahlefeld W 1974. L-(+)-Lactate. Determination with lactate dehydrogenase and NAD. In: Methods of Enzymatic Analysis. Edited by Bermeyer HU. Academic Press, New York, USA; Vol. 2, p. 14641472.

Gutmann I, Bergmeyer HU 1974. Determination of urea, indicator reaction with phenol and hipochlorite. In: Methods of Enzymatic Analysis. Edited by Bermeyer, H.U. Academic Press, New York, USA; Vol. 2, p. 1790-1798.

Hidaka M, Fujita K, Ogikubo T, Yamasaki K, Iwakiri T, Okumura M, Kodama H, Arimori K 2004. Potent inhibition by star fruit of human cytochrome P450 3A (CYP3A) activity. Drug Metab Dispos 32: 581583.

Martha RCD, Poubel J, Ferreira LCL, Lima RS, Borrás MR, Costa PRC, Roland IA 2000. Atividade hipoglicêmica de Averrhoa carambola L. usada em Manaus como antidiabético. NewsLab 38: 142-148.

Massao-Hirabara S, Carvalho CRO, Mendonça JR, Piltcher HE, Fernandes LC, Curi R 2003. Palmitate acutely raises glycogen synthesis in rat soleus muscle by a mechanism that requires its metabolization (Randle cycle). FEBS Lett 24: 109-114.

Neto MM, Robi F, Netto JC 1998. Intoxication by star fruit (Averrhoa carambola) in six dialysis patients. Nephrol Dial Transplant 13: 570-572.

Niticharoenpong K, Chalermsanyakorn P, Panvichian R, Kitiyakara C 2006. Acute deterioration of renal function induced by star fruit ingestion in a patient with chronic kidney disease. J Nephrol 19: 682-686.

Provasi M, Oliveira CE, Martino MC, Pessini LG, Bazotte RB, Cortez AG 2001. Avaliação da toxicidade e do potencial antihiperglicemiante da Averrhoa carambola L. (Oxalidaceae). Acta Scientiarum 23: 665-669.

Provasi M, Oliveira CE, Fernandes LC, Tchaikowiski O, Bazotte RB, Cortez LER, Cortez DAG 2005. Efeito do extrato bruto hidroalcoolico de folhas da Averrhoa carambola L. (Oxiladaceae) no metabolismo glicêmico de ratos wistar. Acta Scientiarum 27: 4548.

Pushparaj PN, Tan CH, Tan BK 2000. Effects of Averrhoa bilimbi leaf extract on blood glucose and lipids in streptozotocin-diabetic rats. J Ethnopharmacol 72: 69-76.
Silva GEC, Takahashi M, Eik-Filho W, Albino CC, Tasin GE, Ferri LAF, Assef AH, Cortez DAG, Bazotte RB 2004. Ausência de efeito hipolipemiante da Solanum melongena L. (Berinjela) em pacientes hiperlipidêmicos. Arq Bras Endocrinol Metabol 48: 368-373.

Siqueira VLD, Cortez DAG, Oliveira CE, Nakamura CV, Bazotte RB 2006. Pharmacological studies of Cordia salicifolia Cham in normal and diabetic rats. Braz Arch Biol Technol 49: 215-218.

Wang YC, Liu BM, Supernaw RB, Lu YH, Lee PY 2006. Management of star fruit-induced neurotoxicity and seizures in a patient with chronic renal failure. Pharmacotherapy 26: 143-146. 